\title{
Challenges and Benefits of Standardising Early Warning Systems: A Case Study of New Zealand's Volcanic Alert Level System
}

\author{
Sally H. Potter, Bradley J. Scott, Carina J. Fearnley ${ }^{0}$, \\ Graham S. Leonard and Christopher E. Gregg
}

\begin{abstract}
Volcano early warning systems are used globally to communicate volcano-related information to diverse stakeholders ranging from specific user groups to the general public, or both. Within the framework of a volcano early warning system, Volcano Alert Level (VAL) systems are commonly used as a simple communication tool to inform society about the status of activity at a specific volcano. Establishing a VAL system that is effective for multiple volcanoes can be challenging, given that each volcano has specific behavioural characteristics. New Zealand has a wide range of volcano types and geological settings, including rhyolitic calderas capable of very large eruptions $\left(>500 \mathrm{~km}^{3}\right)$ and frequent unrest episodes, explosive andesitic stratovolcanoes, and effusive basaltic eruptions at both caldera and volcanic field settings. There is also a range in eruption frequency, requiring the VAL system to be used for both frequently active 'open-vent' volcanoes, and reawakening 'closed-vent' volcanoes. Furthermore, New Zealand's volcanoes are situated in a variety of risk settings ranging from the Auckland Volcanic Field, which lies beneath a city of 1.4 million people; to Mt. Ruapehu, the location of popular ski fields that are occasionally impacted by ballistics and lahars, and produces tephra that falls in distant cities. These wide-ranging characteristics and their impact on society provide opportunities to learn from New Zealand's
\end{abstract}

S.H. Potter $(\bowtie) \cdot$ B.J. Scott · C.J. Fearnley ·

G.S. Leonard - C.E. Gregg

Department of Science and Technology, University College London, Gower Street, London WC1E 6BT, UK

e-mail: S.Potter@gns.cri.nz

C.J. Fearnley

e-mail: c.fearnley@ucl.ac.uk

S.H. Potter - G.S. Leonard

GNS Science, 1 Fairway Drive, Avalon,

Lower Hutt 5010, New Zealand

e-mail: G.Leonard@gns.cri.nz

\section{B.J. Scott}

GNS Science, 114 Karetoto Road, RD4,

Taupo 3384, New Zealand

e-mail: B.Scott@gns.cri.nz

C.E. Gregg

Department of Geosciences, East Tennessee

State University, Box 70357, Johnson,

TN 37614, New Zealand

e-mail: GREGG@mail.etsu.edu 
experience with VAL systems, and the adoption of a standardised single VAL system for all of New Zealand's volcanoes following a review in 2014. This chapter outlines the results of qualitative research conducted in 2010-2014 with key stakeholders and scientists, including from the volcano observatory at GNS Science, to ensure that the resulting standardised VAL system is an effective communication tool. A number of difficulties were faced in revising the VAL system so that it remains effective for all of the volcanic settings that exist in New Zealand. If warning products are standardised too much, end-user decision making and action can be limited when unusual situations occur, e.g., there may be loss of specific relevance in the alert message. Specific decision-making should be based on more specific parameters than the VAL alone, however wider VAL system standardisation can increase credibility, a known requirement for effective warning, by ensuring that warning sources are clear, trusted and widely understood. With a credible source, user groups are less likely to look for alternatives or confirmation, leading to faster action. Here we consider volcanic warnings within the wider concept of end-to-end multi-hazard early warning systems including detection, evaluation, notification, decision-making and action elements (based on Carsell et al. 2004).

\section{Keywords}

Volcanic Alert Level • Early warning system - Standardisation • New Zealand

\section{Early Warning Systems and Standardisation}

An Early Warning System (EWS) can be defined as a system designed to provide "hazard monitoring, forecasting and prediction, disaster risk assessment, communication and preparedness activities, systems and processes that enables individuals, communities, governments, businesses and others to take timely action to reduce disaster risks in advance of hazardous events" (UN 2003). They are recognized as "a means of getting information about an impending emergency, communicating that information to those that need it, and facilitating good decisions and timely response by people in danger" (Mileti and Sorensen 1990 , p. 2-1). Essentially EWSs facilitate the provision of timely warnings to minimize loss of life and to reduce economic and social impact on vulnerable populations (Garcia and Fearnley 2012).

The operation of an EWS presents numerous challenges due to variations in: scale (global, national, regional, local); temporality (rapid onset, slow onset, frequent, infrequent); function (safety, property, environment); and hazard (e.g., weather, climate, geohazards). A Volcano Alert Level (VAL) system is a communication tool within a volcano EWS, which simplifies the communication of volcanologists' interpretation of data (Newhall 2000). The VAL system is disseminated with supporting information that provides more specific details and local context to enable responding agencies, the public, and other stakeholders to make informed decisions (Fearnley 2011; Potter et al. 2014). The levels can be labelled using words, numbers, colours, and/or symbols, and summarise information from 
'background' activity (no unrest), through to the highest level of activity (usually a large eruption) (Newhall 2000; Fearnley 2011).

Volcano observatories play a key role in the management and assignment of alert levels for volcanoes. However, with over 80 volcano observatories around the world, it is understandable that VAL systems operate in very different ways. Some provide only scientific advice on what a volcano is doing, others forecast activity, and others provide guidance on what vulnerable populations should do. There is a growing discussion globally around the role of VAL systems and whether they should be standardised, either nationally and/or internationally.

In 1989, the member states of the United Nations declared the period from 1990 to the year 2000 to be the International Decade for Natural Disaster Reduction (IDNDR) to focus attention on reducing loss of life, and social and economic disruption caused by natural disasters. Of fundamental importance was the recognition in 1991 of early warnings as a key objective of disaster reduction practices (Maskrey 1997). The United Nations has called for more effective procedures via standardisation and the application of new technologies and enhanced scientific understanding (United Nations 2006) but few hazards have an EWS operating beyond a national or regional scale. The most successful example is the Pacific Tsunami Warning Centre (PTWC), established in Hawaii in 1949. Until recently, PTWC provided Warning and Watch alert level services for numerous Pacific nations and beyond, but currently they provide nations with threat level information (e.g., wave amplitude forecasts), which the countries then use in-house to develop and disseminate specific tsunami alert levels (i.e., Warning, Watch).

The growing pressure on volcano observatories to standardise warnings is felt especially in relation to provision of advice and alert levels to the aviation sector. In 2006, the International Civil Aviation Organization (ICAO) globally standardised a considerable portion of products, including the alert levels (via the Aviation Colour Code (ACC); Table 1), messages to airlines that observatories are expected to provide (via the Volcano Observatory Notice for Aviation; VONA), and the framework for monitoring and alerting related to ash clouds (via the Volcanic Ash Advisory Centres; VAACs). While VAACs provide the aviation community with information regarding where ash currently is in the air, the role of the ACC is more about warning (Gardner and Guffanti 2006). The ACC allows a recognition of the level of volcano activity for the purpose of attention by the aviation industry, and to inform their decisions, such as regarding re-routing or extra fuel (Gardner and Guffanti 2006). VONAs are standardised plain-English messages aimed at dispatchers, pilots, and air-traffic controllers 'produced by Volcano Observatory scientists and are based on analysis of data from monitoring networks, direct observations, and satellite sensors' (as described on the USGS website ${ }^{1}$ ). The international nature of these aviation products reflects the need for aviation personnel to ascertain the status of volcanic activity across a number of countries and VAL systems (e.g., Guffanti and Miller 2013), which is why a standardised approach is used. While working fine for international air traffic, problems have been encountered for low-level domestic and private aviation with the ACC (Fearnley 2011).

Numerous volcano observatories across the world are now implementing the ACC, and many of these are questioning the adoption of other VAL systems for ground-based hazards and reviewing their volcano early warning systems. This includes reviewing the effectiveness of VAL issuances, as Winson et al. (2014, p. 12) invite "countries to perform their own self-evaluation and weigh the cost of a higher number of alerts against the benefit of a higher accuracy in VAL issuances and to decide how to proceed accordingly with their own local populations".

The benefits of standardisation are principally:

- simplicity through application of common language, frameworks and understanding;

- clarity for emergency responders;

${ }^{1}$ https://volcanoes.usgs.gov/vhp/notifications.html accessed 11 May 2017. 
- reduced workload for monitoring and emergency management agencies, including education and outreach;

- interoperability of equipment and systems across hazards, and across agencies, countries or internationally.

Warning messages with specific language and approaches can benefit from standardisation. In doing so, it is advisable to publish and make accessible the definitions of technical volcanic terms, and of the words 'risk' and 'hazard' as used by the scientists. This is to ensure local users understand the intention behind the scientist's use of the terms. For example, calculation of 'hazard' can be based on previous events, deterministic and/or probabilistic approaches, and should be described. In addition, the communication of likelihood/probability can also be a point of confusion; ideally numeric values should be mapped against qualitative descriptions and both presented together (e.g., Doyle and Potter 2016). Standardisation can also increase credibility, a known requirement for effective warning, by producing warnings that are clear, and from a trusted source. With a credible source user groups are less likely to look for alternatives or confirmation, leading to faster action. However, end-user decision making and action can be limited in terms of contingent-specific-needs if warning products are standardised too much (e.g., depending on a user's ability to read different types of maps (Haynes et al. 2007); or loss of meaning or relevance in the warning within a local context).

There are various elements of end-to-end warnings that lend themselves to standardisation that can aid the effectiveness of the VAL system:

- Technical: Equipment type, deployment (distribution/location/density), telemetry (radio, wire, internet etc.), visualization (software packages) and analysis all receive some level of standardisation through manufacturing standards, detection limits, and international scientific best practice.
- Analytical tools: Analysis may be further structured through statistical approaches such as expert elicitation, Bayesian event trees or Bayesian belief networks.

- Warning tools: Notification may be standardised through message content (e.g., standard messages, terminology, alert level criteria), packaging (e.g., bulletins, alert levels, maps) and delivery channels (e.g., phone, internet, siren). Some standards lend interoperability, such as a Common Alerting Protocol.

- Response: Decision-making and action by the end-user can be standardised to some extent through communication and education approaches and message content.

Clearly there are cases where standardisation provides many advantages, but the process of standardisation is predominantly triggered and shaped by social, political, and economic factors, rather than in response to scientific needs specific to a region. Standardisation, by definition, tends to exclude the importance of incorporating local factors into a global procedure. Hence, even if standardisation may yield improved strategies for gathering and interpreting warning signals, it will still favour inflexible procedures not designed to accommodate local social and cultural constraints. Challenges are brought about by a range of issues (Fearnley 2011, 2013), especially:

- the realities of varied volcanic systems, each being geophysically unique when examined in detail. The diversity and uncertain nature of numerous hazards that can occur at different temporal and spatial scales require specific EWSs to be developed.

- varied end-users with different needs and perspectives for their decision-making, in terms of the level of volcanic activity, and timing thresholds for response actions.

- multiple local social and cultural contexts and constraints, which presents challenges in relation to the applicability and responsiveness of EWSs to local knowledge and context. 
In recent decades, standardisation within VAL systems at a national level has taken place, making provision for consistency of warnings enacted by civil authorities that are required to take action and facilitate national policies for emergency management. VAL systems in a number of countries (including Japan via the Japan Meteorological Agency (JMA), Vanuatu via GeoHazards, the USA via the USGS, and New Zealand via GNS Science) have been standardised in each country for use by all volcanic observatories. Yet, there are variances in the way VAL systems are being standardised. In the USA, for example, two standardised VAL systems are now in place: a textually based version for ground hazards (e.g., watch, warning) and the aviation colour code that uses colours as labels. In New Zealand, the VAL systems adopted in 1994 and reviewed in 1995 also used two standardised VAL systems: one designed for hazards expected at frequently active volcanoes and the other for restless and reawakening volcanoes (see Table 2). Both of the New Zealand VAL systems were numerically based using six levels ranging from 0 to 5 (Scott and Travers 2009). Another review in 2014 resulted in these two systems being combined into one (Potter et al. 2014), whilst also adopting the international aviation colour code (ACC). Notably, both the USA and New Zealand VAL systems are based upon the current activity of a volcano, and neither advocate action nor provide advice to users involved in crisis management and mitigation - this information is provided in other products. In sharp contrast, the Japanese VAL system addresses the measures to be taken for specific areas of danger, indicating extent of evacuation, and outlining the expected volcanic activity. ${ }^{2}$

This chapter focuses on the standardisation of VAL systems using the case study of New Zealand in the revision of the VAL system in 2014 , to explore the benefits and challenges in implementing a nationally standardised VAL system. Reflections upon its success will help

\footnotetext{
${ }^{2}$ www.data.jma.go.jp/svd/vois/data/tokyo/STOCK/kaisetsu/ English/level.html accessed on 11 May 2017.
}

inform others as to why the devised national alert level in New Zealand is best placed for their nation, and why perhaps an international level of standardisation for VAL systems is still something that is unadvisable, and unfeasible.

\subsection{Overview of New Zealand's Volcanic Risk Setting}

New Zealand straddles the boundary between the Pacific Plate and the Australian Plate. The resulting subduction zone lies beneath a rifting area of thin crust with magmatic upwelling, called the Taupo Volcanic Zone (TVZ; Fig. 1). The TVZ contains most of New Zealand's active volcanoes, and includes stratovolcanoes and calderas.

New Zealand has a range of volcanic risk settings that creates a challenge in effectively communicating scientific information to stakeholders, including the public. In terms of hazard, the volcanoes have large differences in the potential eruption styles and magnitudes of eruptions, reflected by variations in magma chemistry. The past frequency of eruptions and the date of the most recent eruption also vary considerably between them, which contributes towards a range in the likelihood element of the risk equation. The exposure and vulnerability of communities to unrest and eruptions also differs, with some volcanoes (such as Ruapehu, Ngauruhoe, and Tongariro) situated in a largely unpopulated National Park; and others are islands in the Pacific Ocean with few permanent residents (such as Raoul Island in the Kermadecs). Other volcanoes, such as Auckland Volcanic Field, Taupo Volcanic Centre, Okataina Volcanic Centre and Rotorua Caldera volcano, are in close proximity to cities. A few of the volcanoes receive tens of thousands of visitors each year, and are used commercially by tourist operators (including Whakaari/White Island). Others, such as Taranaki volcano, are surrounded by fertile agricultural land and are near important national infrastructure. Each of these elements of risk (hazard characteristics, likelihood, exposure and vulnerability) influence the type of 


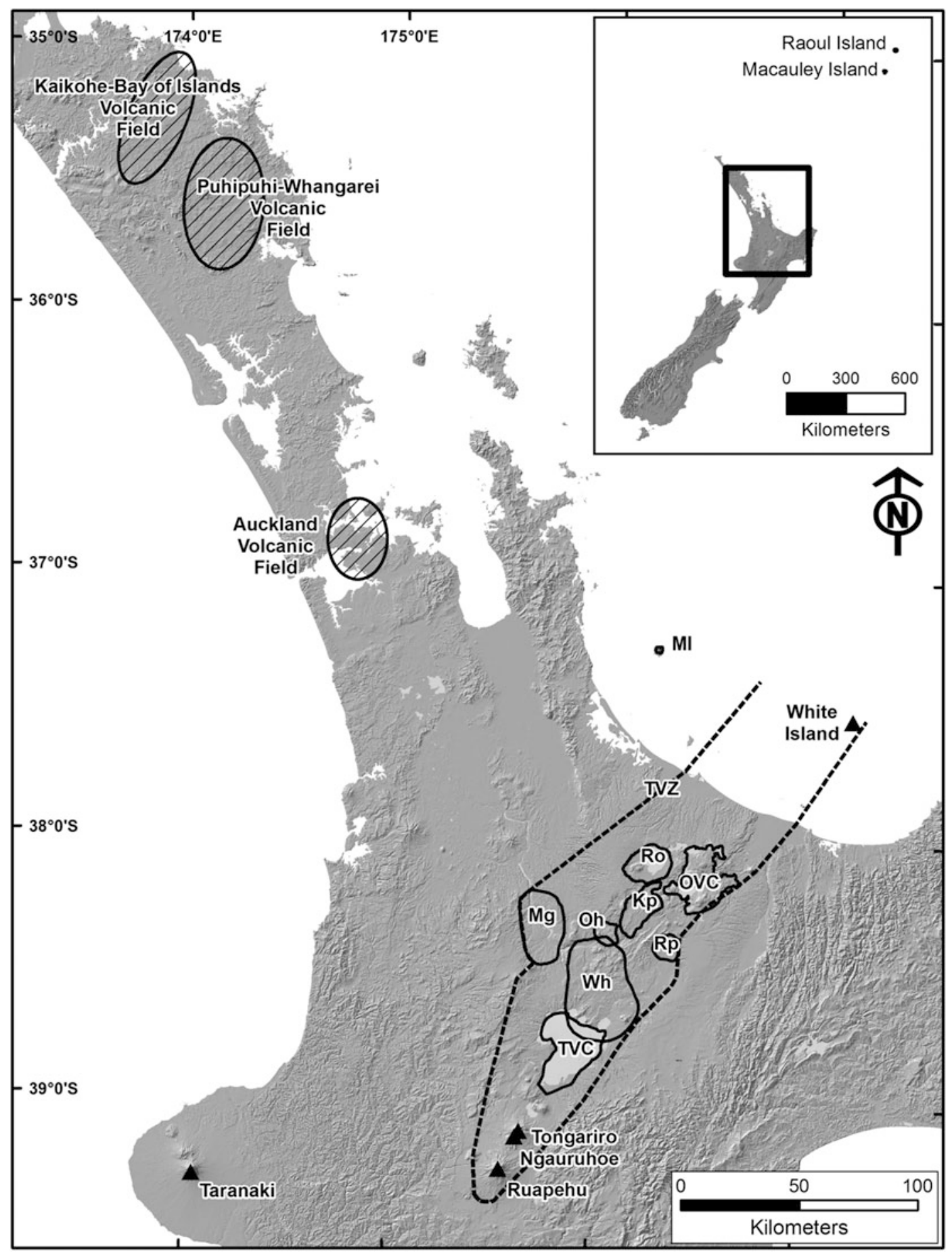

Fig. 1 Map of New Zealand's volcanoes, from Potter (2014), and based on Smith et al. (1993), Nairn (2002), Wilson et al. (2009), and Lindsay et al. (2010). The Taupo Volcanic Zone (TVZ; depicted as a dashed line) envelops the majority of the volcanoes. The calderas (polygons) are
MI Mayor Island; Ro Rotorua; $O V C$ Okataina Volcanic Centre; $K p$ Kapenga; $R p$ Reporoa; Oh Ohakuri; $M g$ Mangakino; Wh Whakamaru; and TVC Taupo Volcanic Centre. The volcanic fields are indicated by ovals with diagonal lines 
Fig. 2 Eruption at Te Maari Crater, Tongariro, on 21 November 2012, captured by the GeoNet Te Maari Crater web camera (GNS Science)

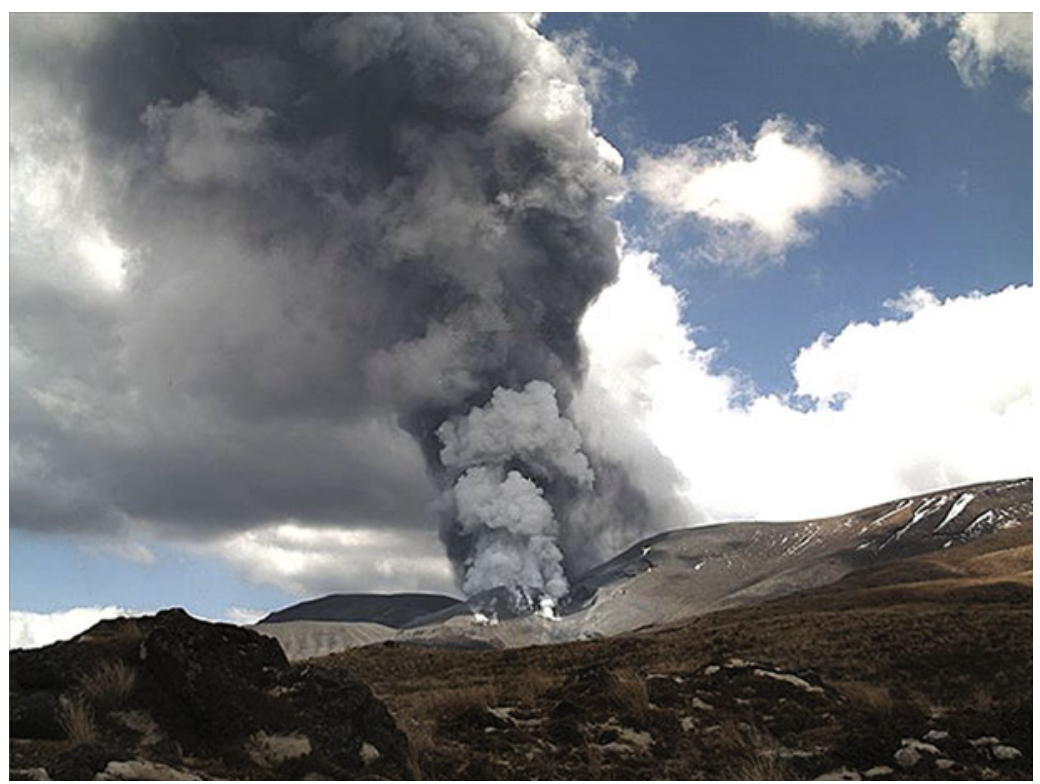

communication and information required, as the local context needs to be considered.

The Tongariro Volcanic Centre is the southernmost volcanic complex of the TVZ, and includes the frequently active andesitic Ruapehu and Ngauruhoe/Tongariro stratovolcanoes. Lahars have frequently occurred, causing a hazard in numerous valleys on the volcanoes (e.g., Leonard et al. 2008). Ruapehu hosts popular ski areas, and last erupted with vigour in 1995-96 (Hurst and McGinty 1999). Small eruptions with short durations also occurred in October 2006 and September 2007. Volcanic unrest is on-going. Ngauruhoe is the most frequently active vent of the Tongariro massif, displaying regular eruptions until 1977 (Scott 1978), but none since. Te Maari Crater and Red Crater on northern Tongariro were active in the late 19th Century, with frequent eruptions in 1896-97 (Scott and Potter 2014). After less than one month of minor unrest, Te Maari Crater was the source of two small, short-lived phreatic eruptions on 6 August and 21 November 2012 (Fig. 2). There were no casualties, however the tourism industry was impacted due to the closure of a popular walking track (the Tongariro Alpine Crossing) by the Department of Conservation (DoC), which manages the National Park.
There are eight areas of known caldera collapse in the central TVZ (Fig. 1), which itself can be considered to be a caldera system similar to Yellowstone in the USA. Although calderas are usually formed in occasional very large eruptions, their magma system can also be the source of many smaller eruptions. The calderas in the TVZ have erupted almost exclusively rhyolitic material in at least 25 caldera-forming eruptions in the last 1.6 million years (Wilson et al. 1984, 2009 ). Only $<0.1 \%$ of the volume of deposits in all of the TVZ are from basaltic eruptions (Wilson et al. 1995). The caldera volcanoes have a large range in past eruption magnitudes. For example, the TVZ's most-recent caldera collapse took place at Taupo Volcanic Centre (TVC) in $232 \pm 5 \mathrm{AD}$, erupting $35 \mathrm{~km}^{3}$ of magma (Wilson 1993; Davy and Caldwell 1998; Self 2006; Hogg et al. 2012). This devastated a significant portion of the central North Island in widespread pyroclastic density currents (Wilson and Walker 1985). However, 26 of the 29 eruptions at TVC in the past 26,000 years (since the last supervolcano eruption) have been much smaller than the most recent eruption (Wilson et al. 2009). Therefore, it is unknown whether future eruptions at TVC will be relatively small, as has been the case most frequently, or 
devastatingly large, as was the case with the most recent eruption. An additional challenge is managing caldera unrest, which can cause social and economic impacts, without a resulting eruption (Potter et al. 2012, 2015).

The north-eastern extremity of the TVZ contains White Island (Whakaari), a privately owned andesitic stratovolcano located $50 \mathrm{~km}$ from the Bay of Plenty coastline. It is currently New Zealand's most frequently active volcano, and a popular tourist destination with approximately 25,000 tourists and tourist operators visiting the island per year. Frequent eruptive sequences have been documented since written records began in 1826 (Nairn et al. 1991), with the most recent eruptions occurring in 2016. New Zealand is also responsible for a number of other island volcanoes, including Mayor Island in the Bay of Plenty, and Raoul and Macauley Calderas in the Kermadec Island chain, 750-1000 km northeast of New Zealand. These islands have very few visitors or residents. About 30 submarine volcanoes are also known in the Kermadec area and some exhibit eruptive activity. Due to the lack of monitoring data, a VAL is not allocated to them.

Taranaki Volcano is a stratovolcano located in the west of the North Island, outside of the TVZ. It is thought to have last erupted in $1755 \mathrm{AD}$ (Druce 1966), but it may have subsequently extruded lava, forming a dome after this date (Platz 2007). It is capable of fairly large eruptions, and has a history of sector collapse (e.g., Neall 2003). Taranaki Volcano is surrounded by productive agricultural land and is in a major hydrocarbon (gas and oil) production region. There is a regional population of just over 100,000 people, most of whom live in the city of New Plymouth.

The intraplate Puhipuhi-Whangarei Volcanic Field (PWVF), the Kaikohe-Bay of Islands Volcanic Field (KBOIVF) and Auckland Volcanic Field (AVF) are in northern New Zealand (Fig. 1). PWVF is thought to have been active as recently as $0.26 \mathrm{Ma}$, while dating of the KBOIVF indicates an eruption occurred at about $0.05 \mathrm{Ma}$ (Smith et al. 1993), or perhaps as recently as in 200-500 AD (Kear and Thompson
1964). AVF has had many eruptions from at least 53 basaltic vents, most recently about 600 years ago (e.g., Needham et al. 2011). Auckland city hosts a third of New Zealand's population with 1.4 million residents, and is sited directly on top of AVF.

Eruptions from most of New Zealand's volcanoes are likely to impact infrastructure of national importance, including many State Highways and road networks, electricity lines and power stations, train lines, water supplies, and sewage facilities (Wilson et al. 2012). Additionally, industries important to the local, regional, and national economies may be threatened during future eruptions, including the tourism, agricultural, forestry, and hydrocarbon industries.

\subsection{Communication of Volcano- Related Information in New Zealand}

In New Zealand, GNS Science is the agency appointed by the Government to provide scientific advice to local, regional, and central government organisations for geological hazards, as stated in the Guide to the National Civil Defence Emergency Management (CDEM) Plan (MCDEM 2015a) and a Memorandum of Understanding with the Ministry of Civil Defence and Emergency Management (MCDEM)(GNS Science, The Ministry of Civil Defence and Emergency Management 2015). The MOU outlines the obligations of GNS Science for geohazard warnings, whereas the Guide to the CDEM Plan is to assist New Zealand agencies to achieve the objectives of the National CDEM Plan (MCDEM 2015b). New Zealand's volcanoes are today monitored by GNS Science through the GeoNet project (Scott and Travers 2009), funded primarily by the New Zealand Earthquake Commission (EQC).

Volcano-related information is communicated to stakeholders, including the public, in a variety of formats before, during, and after volcanic crises. The primary tool used is the Volcano Alert Bulletin (VAB), supported by web page 
information on GeoNet News, ${ }^{3}$ blogs, news items and social media tools (Facebook, twitter). Volcano hazard and status information is also presented by scientists during meetings, conferences, workshops, and public lectures; websites; in scientific and non-scientific publications; and via the media. Smartphone app push alerts, emails, faxes, pager alerts, and text messages provide one-way information to registered end-users during crises or changes in volcanic activity. Volcanic ash impact posters (a product of the Volcanic Impact Study Group, commissioned by the Auckland Lifelines Group) provide accessible information for critical infrastructure stakeholders (Wilson et al. 2014). Social media and 'ask an expert' interactive online sessions allow questions to be asked by the public and answered by scientists in real-time. Informal conversations during meetings, workshops, or by telephone provide end-users with more specific information from volcanologists, with the opportunity for two-way communication. An example of this is during Volcanic Advisory Group meetings, which are attended by key stakeholders and volcanologists to discuss volcano- and response-related information (Doyle et al. 2011). Long-term hazard maps have been created for some of the more active volcanoes, based on geological evidence of past eruptions (Neall and Alloway 1996; Scott and Nairn 1998). Event-specific hazard maps are created during unrest depending on the situation, likely vent location, and the style and magnitude of the potential eruption, etc. Event-specific hazard maps were created prior to and after the Tongariro eruption in 2012 (Leonard et al. 2014).

New Zealand's VAAC, based at the Meteorological Service of New Zealand Ltd. (MetService) office in Wellington, is designated by the International Airways Volcano Watch system to communicate ash information for a large section of the southwest Pacific, including New Zealand's active volcanoes (Lechner 2012). MetService issues Volcanic Ash Advisories in a text and graphic form, and disseminates a Significant

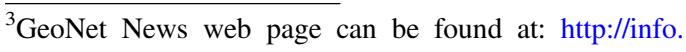
geonet.org.nz/.
}

Meteorological Information (SIGMET) message, while Airways Corporation issue Notice to Airmen (NOTAM), which draws attention to volcanic ash hazards within the NZ VAAC area. These globally standardised messages are also issued when New Zealand's VAL changes, prompting restrictions to local air space. After consultation with GNS Science for NZ volcanoes, Volcanic Ash Advisories are communicated by the VAAC to MCDEM, in addition to being provided to international aviation agencies and meteorological communities (MCDEM 2015a). Volcanic Ash Advisories from MetService forecast the distribution of volcanic ash in the atmosphere for the purpose of aviation safety, whereas GNS Science issues ashfall prediction maps as a VAB, relating to the distribution and thickness of tephra deposits at ground level. In addition to these systems, GNS Science issues Volcano Observatory Notices for Aviation (VONA) to the VAAC to report on ground-based volcanic activity whenever they change the Aviation Colour Code (ACC; Table 1). The ACC is used by the Civil Aviation Authority of New Zealand to alert the aviation industry to changes in the status of volcanoes within the designated coverage area (Lechner 2012).

\subsection{New Zealand's Past VAL Systems}

In New Zealand, scientists at GNS Science determine the VAL as mandated in the Guide to the National CDEM Plan (MCDEM 2015a), with consideration of monitoring data and using their experience and knowledge. When decisions need to be made rapidly (e.g., if an eruption has taken place), the Volcano Duty Officer can make the VAL decision alone. GNS Science, through GeoNet, communicates this information to MCDEM using Volcanic Alert Bulletins. MCDEM forwards this information on to local authorities and CDEM Groups through the National Warning System. GNS Science also disseminates this information to other agencies, the public, and the media (Scott and Travers 2009).

New Zealand's first VAL system (known as the 'Scientific Alert Level' or SAL table; 
Table 2) was introduced in 1994. It was designed by local volcanologists, and included descriptions for different levels of activity for several types of volcanoes, sometimes within a single level of the table. For example, some levels included descriptions for both unrest and eruptions. Later this was to cause confusion as people were not sure which description the assigned VAL referred to.

Several teething issues (including media scrutiny) arose during volcanic unrest at Mt. Ruapehu in late 1994, in part due to the conflicting definitions causing confusion. The original SAL system was therefore reviewed, and a significantly revised and amended version was adopted in September 1995, just one week before the 1995-96 Mt. Ruapehu eruption episode started. The resulting system (Table 3), renamed as the VAL system in 2008 , was divided into two separate sections, one for frequently active volcanoes, and the other for reawakening volcanoes. In addition to a level for 'background activity' (VAL 0), the frequently active volcanoes system included one level for unrest (VAL 1) and four levels of increasing magnitudes of eruption (VAL 2-5), whereas the reawakening volcanoes system included two levels for unrest (VAL 1 and 2) and three eruption levels (VAL 3-5). The VAL system was used until it was again revised in 2014.

The division of the VAL system based on eruptive activity was deemed to be beneficial during the creation of this system because the outcome of unrest was perceived to be more uncertain for reawakening volcanoes than frequently active volcanoes due to no eruptions being witnessed (except for the 1886 eruption at Okataina). Similarly, calderas (which were predominantly in the reawakening volcanoes group) were seen as more likely to exhibit unrest without resulting in an eruption than stratovolcanoes. Many scientists have the perception that end-users, who are more familiar with stratovolcano eruptions, think unrest will predominantly result in an eruption (Potter 2014). Thus, by separating reawakening volcanoes from frequently active volcanoes, it is implied that the volcanoes behave differently, and that unrest at reawakening volcanoes may not result in an eruption. An additional level of heightened unrest was inserted into the reawakening system to help reinforce this meaning.

\section{Reviewing New Zealand's VAL Systems}

While the VAL system that was developed in 1995 performed well for fifteen years, it underwent an exploratory review between 2010 and 2014 to ensure it was the best system possible. Potter et al. (2014) used a qualitative ethnographic methodology consisting of interviews, observations and document analysis to investigate the VAL system, with the involvement of both scientist and end-user groups. For further details on the methodology and full results of this research, refer to Potter et al. (2014) and Potter (2014). Based on the results of this research, the VAL system was revised (Fig. 3) and implemented in collaboration with MCDEM on 1 July 2014.

\subsection{Standardising Multiple Systems into One for All Volcanoes}

Many of the research participants identified the division between frequently active volcanoes and reawakening volcanoes in the 1995-2014 VAL system as a concern (Potter 2014). It was recognised that the use of two systems:

- Complicated a system that was intended to be a simple communication tool.

- May cause confusion in the future if two volcanoes exhibiting different levels of surface activity were allocated the same VAL system.

- May cause confusion because as reawakening volcanoes become more active they may switch sides to become frequently active (and vice versa). This was the case in 2006 when an eruption occurred at Raoul Island.

It was undefined whether the volcanoes were grouped according to the time since the last eruption and/or the recurrence rate of eruptions. 
Table 1 The International Civil Aviation Organization (ICAO) Aviation Colour Code for volcanic activity (ICAO 2004)

\begin{tabular}{l|l|l}
\multicolumn{1}{l}{$\begin{array}{l}\text { ICAO Colour } \\
\text { Code }\end{array}$} & Status of activity of volcano \\
\hline Green & $\begin{array}{l}\text { Volcano is in normal, non-eruptive state } \\
\text { Or, after a change from a higher alert level: } \\
\text { Volcanic activity considered to have ceased, and volcano reverted to its normal, non-eruptive } \\
\text { state }\end{array}$ \\
\hline Yellow & $\begin{array}{l}\text { Volcano is experiencing signs of elevated unrest above known background levels } \\
\text { Or, after a change from a higher alert level: }\end{array}$ \\
\hline $\begin{array}{l}\text { Volcanic activity has decreased significantly but continues to be closely monitored for possible } \\
\text { renewed increase }\end{array}$ \\
\hline $\begin{array}{l}\text { Volcano is exhibiting heightened unrest with increased likelihood of eruption. Or, volcanic } \\
\text { eruption is underway with no or minor ash emission [specify ash-plume height if possible] }\end{array}$ \\
\hline Red & $\begin{array}{l}\text { Eruption is forecasted to be imminent with significant emission of ash into the atmosphere likely } \\
\text { Or, eruption is underway with significant emission of ash into the atmosphere [specify ash- } \\
\text { plume height if possible] }\end{array}$ \\
\hline
\end{tabular}

Table 2 Scientific Alert Level table introduced in 1994 (sourced from Annexe C from the CDEM Plan)

\begin{tabular}{l|l|l}
\hline $\begin{array}{l}\text { Scientific } \\
\text { Level }\end{array}$ & Phenomena Observed & Scientific Interpretation \\
\hline 1 & Abnormal seismic, hydrothermal or other signatures & $\begin{array}{l}\text { Initial sign of volcano reawakening. } \\
\text { No eruption imminent. } \\
\text { Possible minor activity }\end{array}$ \\
\hline 2 & $\begin{array}{l}\text { Increase in seismic, hydrothermal and other unrest } \\
\text { indicators. Increase from usual background weak } \\
\text { eruptions }\end{array}$ & $\begin{array}{l}\text { Indicators of intrusion process or significant } \\
\text { change in on-going eruptive activity }\end{array}$ \\
\hline 3 & $\begin{array}{l}\text { Relatively high and increasing unrest shown by all } \\
\text { indicators. } \\
\text { Commencement of minor eruptive activity at } \\
\text { reawakening vent(s) or increased vigour of on-going } \\
\text { activity }\end{array}$ & $\begin{array}{l}\text { If increasing trends continue there is a real } \\
\text { possibility of hazardous eruptive activity }\end{array}$ \\
\hline 4 & $\begin{array}{l}\text { Rapid acceleration of unrest indicators. Established } \\
\text { magmatic activity at reawakening vents or significant } \\
\text { change to on-going activity }\end{array}$ & $\begin{array}{l}\text { Hazardous volcanic eruption is now } \\
\text { imminent }\end{array}$ \\
\hline 5 & $\begin{array}{l}\text { Hazardous volcanic eruption in progress } \\
\text { immestruction within the Permanent Danger }\end{array}$ \\
\hline
\end{tabular}

Other criteria for grouping volcanoes were also considered. Options identified included grouping volcanoes by their:

- Type (such as volcanic fields vs. calderas vs. stratovolcanoes)
- Potential size of eruption (however even the most explosive volcanoes predominantly have small eruption sizes)

- Tectonic setting (intraplate vs. subduction zone)

- Typical risk from an eruption (e.g., Auckland Volcanic Field vs. Raoul Island) 
Table 3 New Zealand's VALS used between 1995 and 2014. Reproduced from the MCDEM (2006) Guide to the National CDEM Plan, prior to its 2014 revision

\begin{tabular}{|c|c|c|c|c|}
\hline \multicolumn{2}{|c|}{$\begin{array}{c}\text { Frequently active cone volcanoes } \\
\text { White Island, Tongariro/Ngauruhoe, Ruapehu, } \\
\text { Kermadecs }\end{array}$} & \multirow{3}{*}{$\begin{array}{l}\text { VOLCANIC } \\
\text { ALERT LEVEL }\end{array}$} & \multicolumn{2}{|c|}{$\begin{array}{l}\text { Reawakening volcanoes } \\
\text { Northland, Auckland, Mayor Island, Rotorua, } \\
\text { Okataina, Taupo, Egmont/Taranaki }\end{array}$} \\
\hline Volcano status & Indicative phenomena & & $\begin{array}{l}\text { Indicative } \\
\text { phenomena }\end{array}$ & Volcano status \\
\hline $\begin{array}{l}\text { Usual dormant, or } \\
\text { quiescent state }\end{array}$ & $\begin{array}{l}\text { Typical background } \\
\text { surface activity, } \\
\text { seismicity, deformation } \\
\text { and heat flow at low } \\
\text { levels. }\end{array}$ & & $\begin{array}{l}\text { Typical background } \\
\text { surface activity; } \\
\text { deformation, } \\
\text { seismicity, and heat } \\
\text { flow at low levels. }\end{array}$ & $\begin{array}{l}\text { Usual dormant, } \\
\text { or quiescent } \\
\text { state. }\end{array}$ \\
\hline $\begin{array}{l}\text { Signs of volcano } \\
\text { unrest }\end{array}$ & $\begin{array}{l}\text { Departure from typical } \\
\text { background surface } \\
\text { activity. }\end{array}$ & 1 & $\begin{array}{l}\text { Apparent seismic, } \\
\text { geodetic, thermal or } \\
\text { other unrest } \\
\text { indicators. }\end{array}$ & $\begin{array}{l}\text { Initial signs of } \\
\text { possible volcano } \\
\text { unrest. No } \\
\text { eruption threat. }\end{array}$ \\
\hline $\begin{array}{l}\text { Minor eruptive } \\
\text { activity }\end{array}$ & $\begin{array}{l}\text { Onset of eruptive } \\
\text { activity, accompanied } \\
\text { by changes to } \\
\text { monitored indicators. }\end{array}$ & 2 & $\begin{array}{l}\text { Increase in number } \\
\text { or intensity of unrest } \\
\text { indicators } \\
\text { (seismicity, } \\
\text { deformation, heat } \\
\text { flow and so on). }\end{array}$ & $\begin{array}{l}\text { Confirmation of } \\
\text { volcano unrest. } \\
\text { Eruption threat. }\end{array}$ \\
\hline $\begin{array}{l}\text { Significant local } \\
\text { eruption in } \\
\text { progress. }\end{array}$ & $\begin{array}{l}\text { Increased vigour of } \\
\text { ongoing activity and } \\
\text { monitored indicators. } \\
\text { Significant effects on } \\
\text { volcano, possible } \\
\text { effects beyond. }\end{array}$ & 3 & $\begin{array}{l}\text { Minor steam } \\
\text { eruptions. High } \\
\text { increasing trends of } \\
\text { unrest indicators, } \\
\text { significant effects on } \\
\text { volcano, possible } \\
\text { beyond. }\end{array}$ & $\begin{array}{l}\text { Minor eruptions } \\
\text { commenced. } \\
\text { Real possibility } \\
\text { of hazardous } \\
\text { eruptions }\end{array}$ \\
\hline $\begin{array}{l}\text { Hazardous local } \\
\text { eruption in } \\
\text { progress. }\end{array}$ & $\begin{array}{l}\text { Significant change to } \\
\text { ongoing activity and } \\
\text { monitoring indicators. } \\
\text { Effects beyond volcano. }\end{array}$ & 4 & $\begin{array}{l}\text { Eruption of new } \\
\text { magma. Sustained } \\
\text { high levels of unrest } \\
\text { indicators, significant } \\
\text { effects beyond } \\
\text { volcano. }\end{array}$ & $\begin{array}{l}\text { Hazardous local } \\
\text { eruption in } \\
\text { progress. Large- } \\
\text { scale eruption } \\
\text { now possible. }\end{array}$ \\
\hline $\begin{array}{l}\text { Large hazardous } \\
\text { eruption in } \\
\text { progress. }\end{array}$ & $\begin{array}{l}\text { Destruction with major } \\
\text { damage beyond } \\
\text { volcano. Significant risk } \\
\text { over wider areas. }\end{array}$ & 5 & $\begin{array}{l}\text { Destruction with } \\
\text { major damage beyond } \\
\text { active volcano. } \\
\text { Significant risk over } \\
\text { wider areas. }\end{array}$ & $\begin{array}{l}\text { Large hazardous } \\
\text { volcanic } \\
\text { eruption in } \\
\text { progress. }\end{array}$ \\
\hline
\end{tabular}

- Geographical region (or existing Volcanic Advisory Group).

One VAL system for each volcano was also considered, with the perceived benefit of being locally appropriate. However, this would result in at least 15 systems in New Zealand, most of which require a response by the same group of stakeholders and scientists due to the relatively small population size and land area, and having only one volcano observatory (at GNS Science near the township of Taupo). It is more likely that having multiple systems in this situation will lead to confusion and mismanagement than in a larger country where separate groups of people are responding to the same, familiar volcano over time. Many participants specifically stated that they would not want the over-complication of having too many VAL systems.

The division of volcanoes into separate VAL systems should be considered very carefully. The need for the VAL system to be used as a simple communication tool very likely outweighs any benefits of multiple tailored and more detailed 
Fig. 3 New Zealand's revised VAL system, which was implemented on 1 July 2014. Source Sect. 19 of the Guide to the National CDEM Plan (MCDEM 2015a)

\section{New Zealand Volcanic Alert Level System}

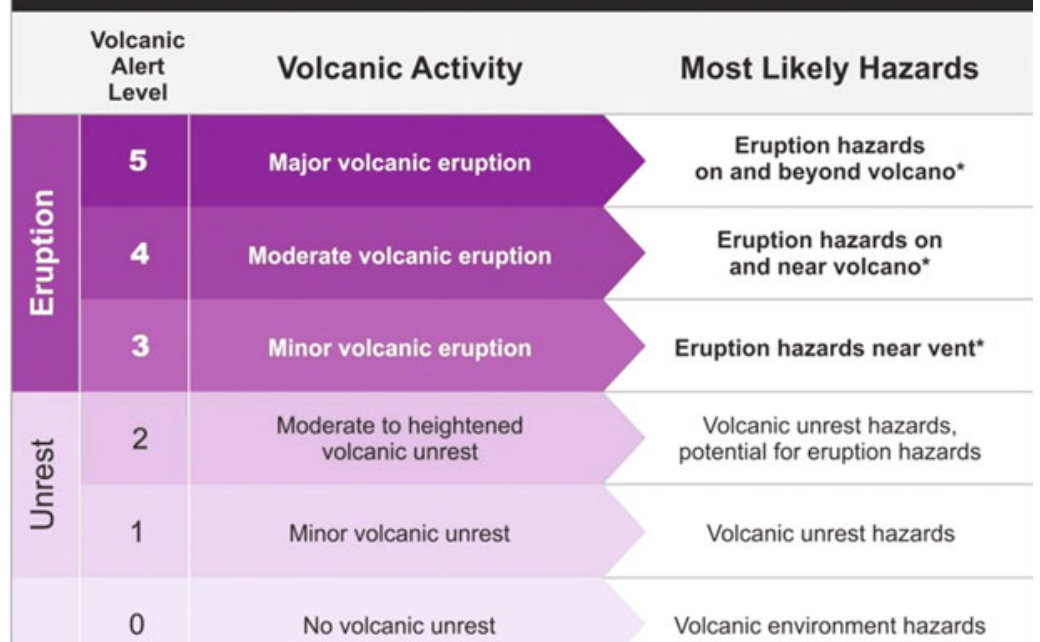

An eruption may occur at any level, and levels may not move in sequence as activity can change rapidly.

Eruption hazards depend on the volcano and eruption style, and may include explosions, ballistics (flying rocks), pyroclastic density currents (fast moving hot ash clouds), lava flows, lava domes, landslides, ash, volcanic gases, lightning, lahars (mudflows), tsunami, and/or earthquakes.

Volcanic unrest hazards occur on and near the volcano, and may include steam eruptions, volcanic gases, earthquakes, landslides, uplift, subsidence, changes to hot springs, and/or lahars (mudflows).

Volcanic environment hazards may include hydrothermal activity, earthquakes, landslides, volcanic gases. and/or lahars (mudflows)

"Ash, lava flow, and lahar (mudflow) hazards may impact areas distant from the volcano.

This system applies to all of New Zealand's volcanoes. The Volcanic Alert Level is set by GNS Science, based on the level of volcanic activity. For more information, see geonet.org.nz/volcano for alert levels and current volcanic activity, gns.cri.nz/volcano for volcanic hazards, and getthru.govt.nz for what to do before, during and after volcanic activity. Version 3.0, 2014.
VAL system. For these reasons, the revised VAL system was designed to be used for all of New Zealand's volcanoes, regardless of factors such as the type, setting, frequency of eruptions, or typical eruption style.

The foundation of the VAL system was also explored in order to determine how the level of volcanic activity could best be communicated (Potter et al. 2014). The 1995-2014 VAL system was based on the severity of the volcano phenomena (e.g., magnitude of eruption); it ranged from 'background activity' to 'large hazardous eruption'. The perceived benefits of this foundation included:

(a) Scientists were most knowledgeable and "comfortable" in determining the severity of phenomena, as opposed to considering other elements of risk. This would lead to less uncertainty and shorter warning times.

(b) The severity of phenomena was seen as the first step in communication, and as being more relevant for a wider range of stakeholders. Interpretation and forecasting information can subsequently be tailored to various audiences, environments, and situations in other communication products.

Various other foundations were considered, including: the level of hazard (taking into account the geological and recent eruptive history of a volcano and spatial extent of hazards, but not the exposure and vulnerability of populations); volcano processes and state of the underlying magma system (ranging from 'no magma' to 'large extrusion of magma'); the level 
of risk (taking into account the severity of the hazard as well as the exposure and vulnerability of populations); or a combination of factors (e.g., focussing on the phenomena during unrest and then on the spatial extent of hazards during eruptions). Research participants were asked for their preference of these options; scientists preferred the phenomena-based system, while stakeholders were more evenly spread but had a slight preference for a combined foundation. They also suggested other types of VAL systems, particularly retaining a phenomena-based system that also included hazard information. As stated by a stakeholder in the CDEM sector:

The phenomenon-based system helps me understand what is going on and the relative severity of the event. The hazard-based system sets out clearly what needs to be done as a consequence. In terms of my CDEM responsibilities, we need bothpeople get twitchy about instructions given without context and justification.

During the final feedback process, this phenomena foundation system accompanied by hazard information was found to be useful and acceptable for all of New Zealand's volcanoes in their varied risk environments.

\subsubsection{Other Considerations When Standardising the VAL System}

Very careful consideration was given to all words in the VAL system (Fig. 3) by its developers (Potter 2014; Potter et al. 2014). Not only did it need to be effective during escalation, de-escalation and static levels of volcanic activity, it also needed to be appropriate for the wide range of volcano types and settings in New Zealand. For example, the term 'vent' was used in VAL 3 in the hazard column instead of 'crater' because some volcanoes have very large craters (e.g., Taupo), or an eruption may occur from a vent on a volcano flank. The use of 'vent', 'near volcano' and 'beyond volcano' is part of the introduction of a dimensionless nomenclature to the VAL system.

No eruption forecasting language was included in the VAL system (beyond 'potential for eruption hazards' in VAL 2), because the capabilities and experience of the volcanologists in forecasting at each of New Zealand's volcanoes is unequal. The use of each phenomena-based alert level would be restricted by the associated description of the expected future activity, which at some of New Zealand's volcanoes, will be very uncertain. For example, if statements such as 'eruption expected within the next two weeks' were included in VAL 2 , volcanologists would not be able to communicate that a volcano was showing heightened levels of unrest unless they also thought that an eruption was expected within the next two weeks. Forecasting information specific to each volcano is instead included in supplementary information, particularly Volcanic Alert Bulletins (VABs).

Because the VAL system needs to be standardised for use at multiple volcanoes, the wording needed to be very simple. Therefore, terms such as 'minor', 'moderate' and 'major' volcanic eruption needed to be defined in order for scientists to use the system consistently between volcanoes, between each other when voting on the VAL, and over time. A GNS Science guideline document has been drafted for this purpose with examples of typical activity shown at each VAL by various volcanoes. This approach was taken rather than describing monitoring criteria thresholds (e.g., rate of earthquakes or rate of deformation), to ensure the system can be used for every volcano regardless of its setting, and to give the scientists more flexibility. A GNS Science YouTube video ${ }^{4}$ was developed to help communicate the typical levels of activity for each of the VAL systems to the public and stakeholders.

\section{Lessons Learnt from the NZ Case Study in Relation to the Standardisation of VAL System}

When considering whether to utilise a standardised warning approach, Potter et al. (2014) explored the purpose of the VAL system, the information needs of New Zealand's

\footnotetext{
${ }^{4}$ www.youtube.com/watch?v=WeZxW2xyam0\&list=UUTL_ U_K1eP4T885-JL3rVgw, accessed on 11 May 2017.
} 
stakeholders, and the capabilities of the volcano monitoring system. They paid particular attention to the benefits and challenges of combining warning systems for all of the volcanoes into one. This included determining the foundation of the VAL system, the words used in the table, whether forecasting language should be included, and how the system was going to be used consistently over time and at multiple volcanoes. As identified by the IDNDR Early Warning Programme Convenors (1997), locally appropriate communication methods should be established for the distribution of warnings. The social science research used for this investigation was a robust process that enabled the revision of the VAL system to be based on evidence, as advocated by Leonard and Potter (2015). The resulting VAL system has been used for all of New Zealand's volcanoes since June 2014. It has worked satisfactorily to date. For example, volcanic unrest or eruptions with which the revised system has been successfully used have included: unrest at Ngauruhoe (VAL raised to 1 and later lowered); decrease in unrest at Te Maari (VAL lowered to 0); and small eruptions at White Island (VAL raised to 3 and lowered later). Volcanologists at GNS Science have found the simple descriptions in the revised VAL table beneficial for allowing flexible decision-making when determining the level of activity. Having just one system for all NZ volcanoes has also improved clarity. Regular evaluations of this warning tool will take place in the future, involving stakeholders, volcanologists, and the public. There is more monitoring data and interpretation relevant to end-users and decisions than the VAL itself and in New Zealand such information is included in the accompanying VAB. Based on the recent experiences with review and implementation of New Zealand's VAL systems, we strongly recommend stakeholders consider exactly what parameters, impacts, uncertainties and lead-times are important to each decision that needs to be made (e.g., evacuation) and not simply tie responses to changes in the VAL.

The revised VAL system has been developed for the New Zealand context, including our volcanic settings and risk environments, the roles and responsibilities of our agencies, and our social and cultural environments including the centralised nature of our volcano monitoring and warning system. As such, it is unlikely that it is able to be directly copied for other countries. However, the process that we followed can be used, as summarised in the next section.

\section{Recommendations for Reviewing or Developing a VAL System}

This chapter has focussed on aspects relating to standardisation, when reviewing a VAL system. There are other considerations to take into account as well. We describe below our recommended processes and considerations when reviewing a VAL system (or developing a new one), based on our research and experience.

\section{(1) Understand the context}

It is vital to understand the physical, cultural, social, organisational and historical context of the VAL and related systems. Potter et al. (2014) found that using the qualitative methodology of ethnography allowed a deep understanding of the culture of the volcanologists to be built to address many of the following factors. However, we recognise that this is a time-consuming process that is not an option for many observatories looking to revise their VAL systems. If this is the case, then drawing on published material, attending volcano monitoring meetings, and holding discussions with those familiar with the various environments should be sufficient. We recommend understanding as much as possible about the:

- Range of potential volcanic activity at every volcano that the VAL system may be used for, including frequency of eruptions, level of ongoing unrest or eruptions, potential magnitude of eruptions (and unrest phenomena), and severity of all possible hazards.

- Volcano monitoring system to understand capabilities and factors such as timing, uncertainties and content of incoming data. 
- Level of exposure and vulnerability of elements at risk to volcanic hazards, including the built, social, economic and natural environments.

- Roles and responsibilities, including legislative requirements, of scientific advisors from all institutions, and organisations with the role of planning, education, response and recovery from volcanic events (including governmental and civil defence agencies, infrastructure/ lifelines, emergency services, health, agricultural/horticultural and business sectors). For example, understand which agencies have the responsibility to communicate directly to the public.

- Influences on the VAL decision-making process. This includes understanding the cultures of people/groups determining the VAL system, and the receivers of the information including decision-makers and stakeholders, and the public. For example, influences on the VAL decision-making process may include experience, external pressure, peer pressure and other social psychology biases, internal voting guidelines, how individuals interpret the content and structure of the VAL system, and the desire to maintain credibility or conduct fieldwork (Potter 2014). Factors such as these contributed towards the design of the revised NZ VAL system. Additionally, understanding the way stakeholders read volcano-related information and use it in their decision-making contributed towards determining what information was included in the NZ VAL system, how it is communicated to them.

- Previous VAL systems, and any other existing alerting systems for volcanic or other hazards used in the country or for the volcano in question. What were people's experiences with those systems? What worked well or didn't work well? Are there any other warning systems being used on or near the volcano, including the international ACC? Understanding VAL systems that have been implemented in other parts of the world is also useful. Being familiar with the challenges and benefits of standardisation as outlined in this chapter is relevant for this point.

- What other communication avenues exist for related information from all agencies? For example, Volcanic Alert Bulletins, phone calls, meetings, websites, emails, social media. These provide the context of whether the VAL system will need to include all important information as a standalone system, or if it can be supported by other channels.

(2) Understand the challenges and benefits of the existing VAL system

It is important to know who the audience is for the VAL system, and what they use it for. If the system is targeted at stakeholders and decision-makers, perhaps more technical and specific information could be included than if the audience includes the public. This information might also inform the position of the divisions between alert levels by matching it to their decision-making needs. However, due to the wide range of stakeholder needs and the differing points at which they need to take action, coupled with a system that communicates to multiple audiences, it is likely that discussions will need to be held to encourage stakeholders to determine their own decision points, rather than them relying on changes in alert levels. Understand their perception of the purpose of the VAL system, and their experiences with any existing VAL systems, through methods such as interviews, open-ended questions in surveys, or workshops/focus groups. Ask the volcanologists (or whomever determines the VAL) what they find useful or challenging, and see if their perceived purpose of the system matches that of the stakeholders/public. Analyse the existing system to identify jargon, unclear meanings, and the foundation of the system. Understand what channels are used to communicate it (such as websites, social media, Bulletins), as this may pose opportunities or limitations in designing a revised system. Ask all parties what they would like to see in a revised system. Determine factors 
such as whether it should include eruption forecasting messages, what its foundation should be based on, and whether it is a standardised system for multiple volcanoes, or specific to a single volcano.

(3) Produce a draft version of the revised VAL system and seek feedback

By considering the context, and collating the information outlined in step 2, recommendations for a revised system can be developed. Based on those recommendations, a draft version (or multiple options) can be developed. Both the summarised findings and the $\operatorname{draft}(\mathrm{s})$ can then be circulated back to participants to ensure their perceptions and needs have been accurately captured. For the NZ revision, Potter (2014) asked participants to rank five draft versions, which helped to determine the most appropriate foundation and structure of the revised VAL system. Multiple iterations then occurred to produce the final version. Do not underestimate the amount of time needed for this process! A final version of the VAL system can now be developed (consider utilising graphics specialists).

(4) Release revised system in collaboration with stakeholders

In conjunction with key stakeholders, determine a date on which the new system will be used, taking into account the length of time all parties need to update documentation, websites, etc. Release communications to circulate the change in VAL system through the media, stakeholder newsletters, meetings, etc. In NZ, GNS Science developed a media release six weeks prior to the start date of the system, and on the day of the changeover, with support from MCDEM. Make a plan for if a new eruptive episode should start close to the changeover date (thankfully no eruptions occurred for the changeover date in NZ!). Write any supporting documentation or procedures, such as a guideline for consistent use by the volcanologists, or whether the VAL system will be used exactly as written or more flexibly.

\section{(5) Evaluate the revised VAL System}

Conduct regular evaluations to ensure the revised (or new) VAL system is effective, and meeting the needs of stakeholders, the public, and volcanologists. Real events and exercises can be used.

\section{Volcanic Crisis Communication}

Warnings about natural hazard events are communicated in order to minimise losses (Newhall 2000). However, trust and communication networks must already be in place prior to a crisis for effective planning and response. This can be achieved by developing networks, ascertaining information needs and establishing methods of effective communication (Paton et al. 1998). VAL systems are just one aspect of an EWS, and by design are the simplest tool to communicate the status of the volcano (or level of response required, etc.). Due to this overarching purpose, standardising VAL systems can help ensure a consistent, simple, and understandable design. As we have outlined in this chapter however, there are issues with using a one-size-fits-all communication product. This was also identified by Thompson et al. (2015) in using probabilistic volcanic hazard maps. We found that taking into account the local context is vital, which supports the findings of numerous recent research in volcanic crisis communication (Haynes et al. 2007; Fearnley et al. 2012; Potter et al. 2014). Providing supporting information using other means helps to alleviate these issues.

Over the past two decades, social science has increasingly played a valuable role in mitigating volcanic risks by providing evidence-based links between communities, stakeholders and scientists (Barclay et al. 2008; Leonard and Potter 2015). We recommend that in the future these robust methodologies are embraced by volcano observatories, such as when revising 
communication strategies and products, to help effectively share information and reduce the risk to society.

Acknowledgements The authors would like to thank all research participants, supervisors and colleagues for their contribution to this research. The research was primarily funded by the Government of New Zealand through the Natural Hazards Research Platform, and through the Earthquake Commission.

\section{References}

Barclay J, Haynes K, Mitchell T, Solana C, Teeuw R, Darnell A, Crosweller HS, Cole P, Pyle D, Lowe C, Fearnley C (2008) Framing volcanic risk communication within disaster risk reduction: finding ways for the social and physical sciences to work together. Geol Society Lond Spec Publ 305(1):163-177

Carsell KM, Pingel ND, Ford DT (2004) Quantifying the benefit of a flood warning system. Nat Hazards Rev 5(3):131-140

Davy BW, Caldwell TG (1998) Gravity, magnetic and seismic surveys of the caldera complex, Lake Taupo, North Island, New Zealand. J Volcanol Geoth Res 81:69-89

Doyle EEH, Potter SH (2016) Methodology for the development of a probability translation table for GeoNet. GNS Science report 2015/67. GNS Science, Lower Hutt, New Zealand, p 18

Doyle EE, Johnston DM, McClure J, Paton D (2011) The communication of uncertain scientific advice during natural hazard events. NZ J Psychol 40(4):39-50

Druce AP (1966) Tree-ring dating of recent volcanic ash and lapilli, Mt Egmont. NZ J Bot 4(1):3-41

Fearnley CJ (2011) Standardising the USGS volcano alert level system: acting in the context of risk, uncertainty and complexity. Ph.D thesis, University College London, London, UK

Fearnley CJ (2013) Assigning a volcano alert level: negotiating uncertainty, risk, and complexity in decision-making processes. Enviro Plan A 45(8): 1891-1911

Fearnley CJ, McGuire WJ, Davies G, Twigg J (2012) Standardisation of the USGS Volcano Alert Level System (VALS): analysis and ramifications. Bull Volc 74(9):2023-2036

Garcia C, Fearnley CJ (2012) Evaluating critical links in early warning systems for natural hazards. Environ Hazards 11(2):123-137

Gardner CA, Guffanti MC (2006) U.S. geological survey's alert notification system for volcanic activity. U.S. Geological Survey Fact Sheet 2006-3139. U S Geol Surv

GNS Science, The Ministry of Civil Defence and Emergency Management (2015) Memorandum of understanding between the Ministry of Civil Defence
\& Emergency Management (MCDEM) and Institute of Geological and Nuclear Sciences Limited (GNS Science) for the engagement of geoscience and Civil Defence Emergency Management. pp 18

Guffanti MC, Miller TP (2013) A volcanic activity alert-level system for aviation: review of its development and application in Alaska. Nat Hazards 69:15191533. doi:10.1007/s11069-013-0761-4

Haynes K, Barclay J, Pidgeon N (2007) Volcanic hazard communication using maps: an evaluation of their effectiveness. Bull Volc 70(2):123-138. doi:10.1007/ s00445-007-0124-7

Hogg A, Lowe DJ, Palmer J, Boswijk G, Ramsey CB (2012) Revised calendar date for the Taupo eruption derived by ${ }^{14} \mathrm{C}$ wiggle-matching using a New Zealand kauri ${ }^{14} \mathrm{C}$ calibration data set. Holocene 22(4): 439-449

Hurst AW, McGinty PJ (1999) Earthquake swarms to the west of Mt Ruapehu preceding its 1995 eruption. J Volcanol Geoth Res 90(1-2):19-28

ICAO (2004) Handbook on the International Airways Volcano Watch (IAVW). Doc 9766-AN/968: International Civil Aviation Organization (ICAO)

IDNDR early warning programme convenors (1997) Guiding principles for effective early warning. Convenors of the international expert groups on early warning. United nations international decade for natural disaster reduction, Geneva, Switzerland

Kear D, Thompson BN (1964) Volcanic risk in Northland. NZ J Geol Geophys 7(1):87-93

Lechner P (2012) Living with volcanic ash episodes in civil aviation: the New Zealand Volcanic Ash Advisory System (VAAS) and the International Airways Volcano Watch (IAVW) Civil Aviation Authority of New Zealand

Leonard G, Potter S (2015) Developing effective communication tools for volcanic hazards in New Zealand, using social science. In: Loughlin SC, Sparks S, Brown SK, Jenkins SF, Vye-Brown C (eds) Global volcanic hazards and risk. Cambridge University Press, Cambridge, UK, pp 305-310

Leonard GS, Johnston DM, Paton D, Christianson A, Becker J, Keys H (2008) Developing effective warning systems: ongoing research at Ruapehu volcano, New Zealand. J Volcanol Geoth Res 172(3-4):199215. doi:10.1016/j.jvolgeores.2007.12.008

Leonard GS, Stewart C, Wilson TM, Procter JN, Scott BJ, Keys HJ, Jolly GE, Wardman JB, Cronin SJ, McBride SK (2014) Integrating multidisciplinary science, modelling and impact data into evolving, syn-event volcanic hazard mapping and communication: a case study from the 2012 Tongariro eruption crisis, New Zealand. J Volcanol Geoth Res 286:208232. doi:10.1016/j.jvolgeores.2014.08.018

Lindsay J, Marzocchi W, Jolly G, Constantinescu R, Selva J, Sandri L (2010) Towards real-time eruption forecasting in the Auckland Volcanic Field: application of BET_EF during the New Zealand national disaster exercise 'Ruaumoko'. Bull Volc 72(2):185204. doi:10.1007/s00445-009-0311-9 
Maskrey MA (1997) IDNDR Secretariat, Geneva, Oct 1997

MCDEM (2015a) The guide to the National Civil Defence Emergency Management Plan 2015. Ministry of Civil Defence \& Emergency Management, Wellington. Retrieved from http://www.civildefence. govt.nz/assets/guide-to-the-national-cdem-plan/Guideto-the-National-CDEM-Plan-2015.pdf

MCDEM (2015b) National Civil Defence Emergency Management plan order 2015. (2015/140) Ministry of Civil Defence and Emergency Management,New Zealand. Retrieved from http://www.legislation.govt. nz/regulation/public/2015/0140/latest/DLM6486453. html? src $=\mathrm{qs} \% 20$

Mileti DS, Sorensen JH (1990) Communication of emergency public warnings - a social science perspective and state-of-the-art assessment. Laboratory, Oak Ridge National, p 166

Nairn IA (2002) Geology of the Okataina Volcanic Centre. Geological map 25, scale 1:50 000, 1 sheet +156 p. Institute of Geological \& Nuclear Sciences Limited, Lower Hutt

Nairn IA, Houghton BF, Cole JW (1991) Volcanic hazards at White Island. Volcanic hazards information series, vol 3. Ministry of Civil Defence

Neall VE (2003) The volcanic history of Taranaki. Massey University, Palmerston North, New Zealand, Institute of Natural Resources

Neall VE, Alloway BV (1996) Volcanic hazards at Egmont Volcano; volcanic hazard map of western Taranaki. Volcanic hazards information series, vol 12. Occasional Report. Massey University, New Zealand

Needham AJ, Lindsay JM, Smith IEM, Augustinus P, Shane PA (2011) Sequential eruption of alkaline and sub-alkaline magmas from a small monogenetic volcano in the Auckland Volcanic Field, New Zealand. J Volcanol Geoth Res 201(1-4):126-142. doi:10.1016/j.jvolgeores.2010.07.017

Newhall CG (2000) Volcano warnings. In: Sigurdsson H, Houghton BF, McNutt SR, Rymer H, Stix J (eds) Encyclopedia of Volcanoes. Academic Press, San Diego, CA, pp 1185-1197

Paton D, Johnston DM, Houghton B (1998) Organisational response to a volcanic eruption. Disaster Prev Manage 7(1):5-13

Platz T (2007) Aspects of dome-forming eruptions from andesitic volcanoes through the Maero Eruptive Period (1000 yrs B.P. to present): activity at Mt. Taranaki, New Zealand. Ph.D thesis, Massey University, Palmerston North, New Zealand

Potter SH (2014) Communicating the status of volcanic activity in New Zealand, with specific application to caldera unrest. Ph.D thesis, Massey University, Wellington, New Zealand. Retrieved from http://mro. massey.ac.nz/handle/10179/5654

Potter SH, Scott BJ, Jolly GE (2012) Caldera unrest management sourcebook. GNS Science Report 2012/12. GNS Science, Lower Hutt, New Zealand, p 73
Potter SH, Jolly GE, Neall VE, Johnston DM, Scott BJ (2014) Communicating the status of volcanic activity: revising New Zealand's volcanic alert level system. J Appl Volcanol 3(13)

Potter SH, Scott BJ, Jolly GE, Johnston DM, Neall VE (2015) A catalogue of caldera unrest at Taupo Volcanic Centre, New Zealand, using the Volcanic Unrest Index (VUI). Bull Volc 77:78. doi:10.1007/ s00445-015-0956-5

Scott BJ (1978) Volcano and geothermal observations 1977: observed activity at Ngauruhoe. New Zealand Volcanological Record (pp 44-45): NZ Geol Surv, DSIR

Scott BJ, Nairn IA (1998) Volcanic hazards: Okataina volcanic centre. Scale 1:100,000: Bay of Plenty Regional Council. Resource planning publication/Bay of Plenty Regional Council, New Zealand 97/4

Scott BJ, Potter SH (2014) Aspects of historical eruptive activity and volcanic unrest at Mt. Tongariro, New Zealand: 1846-2013. J Volcanol Geoth Res 286 (Special issue: Tongariro Eruption 2012):263-276

Scott BJ, Travers J (2009) Volcano monitoring in NZ and links to SW Pacific via the Wellington VAAC. Nat Hazards 51(2):263-273. doi:10.1007/s11069-0099354-7

Self S (2006) The effects and consequences of very large explosive volcanic eruptions. Philos Trans R Soc A Math Phys Eng Sci 364(1845):2073-2097. doi:10. 1098/rsta.2006.1814

Smith IEM, Okada T, Itaya T, Black PM (1993) Age relationships and tectonic implications of late Cenozoic basaltic volcanism in Northland, New Zealand. NZ J Geol Geophys 36(3):385-393

Thompson MA, Lindsay JM, Gaillard JC (2015) The influence of probabilistic volcanic hazard map properties on hazard communication. J Appl Volcanol 4(1): $1-24$

UN ISDR (2003) Terminology: basic terms of disaster risk reduction retrieved 25/08/2009, from http://www. unisdr.org/eng/library/lib-terminology-eng\%20home. htm

United Nations (2006) Global survey of early warning systems. Final Version. 46 p. http://www.unisdr.org/ 2006/ppew/info-resources/ewc3/Global-Survey-ofEarly-Warning-Systems.pdf (accessed 20 March 2010)

Wilson CJN (1993) Stratigraphy, chronology, styles and dynamics of late quaternary eruptions from Taupo volcano, New Zealand. Philos Trans Phys Sci Eng 343 (1668):205-306

Wilson CJN, Walker GPL (1985) The Taupo eruption, New Zealand I. General aspects. Philosophical Transactions of the Royal Society of London. Ser A Math Phys Sci 314(1529):199-228

Wilson CJN, Rogan AM, Smith IEM, Northey DJ, Nairn IA, Houghton BF (1984) Caldera volcanoes of the Taupo Volcanic Zone. J Geophys Res 89(B10): 8463-8484 
Wilson CJN, Houghton BF, McWilliams MO, Lanphere MA, Weaver SD, Briggs RM (1995) Volcanic and structural evolution of Taupo Volcanic Zone, New Zealand-a review. J Volcanol Geoth Res 68(1-3): $1-28$

Wilson CJN, Gravley DM, Leonard GS, Rowland JV (2009) Volcanism in the central Taupo Volcanic Zone, New Zealand: tempo, styles and controls. Studies in Volcanology: the legacy of george walker. Spec publ IAVCEI 2:225-247

Wilson T, Stewart C, Sword-Daniels V, Leonard GS, Johnston DM, Cole JW, Wardman J, Wilson GJ,
Barnard ST (2012) Volcanic ash impacts on critical infrastructure. Phys Chem Earth Parts A/B/C 4546:5-23

Wilson T, Stewart C, Wardman JB, Wilson G, Johnston DM, Hill D, Hampton SJ, Villemure M, McBride S, Leonard G (2014) Volcanic ashfall preparedness poster series: a collaborative process for reducing the vulnerability of critical infrastructure. J Appl Volcanol 3(1):1-25

Winson AE, Costa F, Newhall CG, Woo G (2014) An analysis of the issuance of volcanic alert levels during volcanic crises. J Appl Volcanol 3(1):14
Open Access This chapter is licensed under the terms of the Creative Commons Attribution 4.0 International License (http://creativecommons.org/licenses/by/4.0/), which permits use, sharing, adaptation, distribution and reproduction in any medium or format, as long as you give appropriate credit to the original author(s) and the source, provide a link to the Creative Commons license and indicate if changes were made.
The images or other third party material in this chapter are included in the chapter's Creative Commons license, unless indicated otherwise in a credit line to the material. If material is not included in the chapter's Creative Commons license and your intended use is not permitted by statutory regulation or exceeds the permitted use, you will need to obtain permission directly from the copyright holder. 